\title{
Acute Functional Tolerance to Ethanol Mediated by Protein Kinase $\mathrm{C} \varepsilon$
}

\author{
Melisa J Wallace ${ }^{1,2}$, Philip M Newton ${ }^{1,2}$, Miho Oyasu',2, Thomas McMahon ${ }^{1,2}$, Wen-Hai Chou ${ }^{1,2}$, \\ Jacklyn Connolly ${ }^{1,2}$ and Robert $O$ Messing*, I,2 \\ 'Ernest Gallo Clinic and Research Center, Emeryville, CA, USA; '2Graduate Program in Neuroscience, Department of Neurology, \\ University of California at San Francisco, San Francisco, CA, USA
}

\begin{abstract}
A low level of response to ethanol is associated with increased risk of alcoholism. A major determinant of the level of response is the capacity to develop acute functional tolerance (AFT) to ethanol during a single drinking session. Mice lacking protein kinase $C$ epsilon (PKC $\varepsilon$ ) show increased signs of ethanol intoxication and reduced ethanol self-administration. Here, we report that AFT to the motorimpairing effects of ethanol is reduced in $\mathrm{PKC}_{\varepsilon}(-/-)$ mice when compared with wild-type littermates. In wild-type mice, in vivo ethanol exposure produced AFT that was accompanied by increased phosphorylation of PKC $\varepsilon$ and resistance of GABA $A_{A}$ receptors to ethanol. In contrast, in $\mathrm{PKC} \varepsilon(-/-)$ mice, $\mathrm{GABA}_{\mathrm{A}}$ receptor sensitivity to ethanol was unaltered by acute in vivo ethanol exposure. Both $\mathrm{PKC} \varepsilon(-/-)$ and $\mathrm{PKC}_{\varepsilon}(+/+)$ mice developed robust chronic tolerance to ethanol, but the presence of chronic tolerance did not change ethanol preference drinking. These findings suggest that ethanol activates a $P K C \varepsilon$ signaling pathway that contributes to $G_{A B A} A_{A}$ receptor resistance to ethanol and to AFT. AFT can be genetically dissociated from chronic tolerance, which is not regulated by PKC $\varepsilon$ and does not alter $\mathrm{PKC} \varepsilon$ modulation of ethanol preference.

Neuropsychopharmacology (2007) 32, I27-136. doi:I 0. I038/sj.npp. I 30 I059; published online I5 March 2006
\end{abstract}

Keywords: protein kinase; cerebellum; alcohol; phosphorylation; tolerance; GABA receptor

\section{INTRODUCTION}

Genetic factors account for $50-60 \%$ of the risk of developing an alcohol-use disorder (Prescott and Kendler, 1999). One behavioral characteristic related to this risk is a low level of response to an acute alcohol challenge (Schuckit, 1998), a trait that carries a similar estimated heritability of $40-60 \%$ (Schuckit and Smith, 1996; Heath et al, 1999). Linkage studies have identified regions on chromosomes 10, 11, 13, and 20 with LOD scores $\geqslant 3.0$ that may contain genes that contribute to the level of response to alcohol (Schuckit $e t$ al, 2004). Few genes have been identified, although recently the long allele of the SLC6A4 gene, which encodes the serotonin transporter, and the Ser 385 variant of the GABRA6 gene, which encodes the $\alpha 6$ subunit of $\mathrm{GABA}_{\mathrm{A}}$ receptors, have been associated with a low level of response to alcohol in humans (Hu et al, 2005). The Collaborative Study on the Genetics of Alcoholism has identified the GABRA2 gene

* Correspondence: Dr RO Messing, Ernest Gallo Clinic and Research Center, 5858 Horton Avenue, Suite 200, Emeryville, CA 94608, USA, Tel: + I 510985 3950; Fax: + I 5109853101 ,

E-mail: romes@itsa.ucsf.edu

Received 18 August 2005; revised 27 December 2005; accepted 9 February 2006

Online publication: 9 February 2006 at http://www.acnp.org/citations/ Npp020906050522/default.pdf located on chromosome 4 encoding the $\alpha 2$-subunit of the $\mathrm{GABA}_{\mathrm{A}}$ receptor, the GABRB1 gene on chromosome 4 coding for the $\beta 1$ subunit of the $\mathrm{GABA}_{\mathrm{A}}$ receptor, and the CHRM2 gene on chromosome 7 , which encodes the type 2 muscarinic receptor as susceptibility genes for alcoholism (Dick et al, 2005), although it is not known if they contribute to the level of response to alcohol. In addition, animal studies have identified several other genes that alter acute responses to alcohol in rodents as candidates for the regulation of the level of response in humans (Schuckit et al, 2004).

The level of response to alcohol involves two components: initial sensitivity and acute functional (behavioral) tolerance (AFT). Initial sensitivity is measured as the level of intoxication that appears within minutes after ethanol administration, when blood ethanol levels are rising. AFT is characterized by a greater level of intoxication during the rising phase of the blood ethanol curve than at equivalent concentrations on the falling phase. AFT develops during a single session of ethanol exposure and is not owing to changes in ethanol clearance. It is distinguished from rapid tolerance, which is measured $8-72 \mathrm{~h}$ after an episode of ethanol exposure when ethanol is completely metabolized, and from chronic tolerance, which is the progressive resistance to ethanol intoxication following repeated sessions of ethanol exposure (Kalant et al, 1971; Kalant, 
1996). As the most consistent differences in response to an alcohol challenge in human subjects are detected 60 min or more after ethanol administration when blood alcohol levels are declining, it is likely that they reflect differences in AFT (Schuckit, 1984a, b; Schuckit et al, 1987, 1988; Newlin and Thomson, 1990).

We previously found that mice deficient in protein kinase $\mathrm{C}$ epsilon ( $\mathrm{PKC} \varepsilon$ ) show an increased duration of the ethanol-induced loss of the righting reflex (LORR), a measure of hypnotic response, when compared with wildtype littermates (Hodge et al, 1999). This is associated with a normal response to the direct $\mathrm{GABA}_{\mathrm{A}}$ agonist muscimol, but an increased enhancement of $\mathrm{GABA}_{\mathrm{A}}$ receptor function by ethanol (Hodge et al, 1999; Proctor et al, 2003). As $\mathrm{GABA}_{\mathrm{A}}$ receptor modulation and behavioral responses to benzodiazepines (Hodge et al, 1999) and neurosteroids (Hodge et al, 2001), which also act at $\mathrm{GABA}_{\mathrm{A}}$ receptors, are greater in $\mathrm{PKC} \varepsilon(-/-)$ mice, increased modulation of $\mathrm{GABA}_{\mathrm{A}}$ receptor function by ethanol is likely to explain the enhanced level of response in these mice.

In this study, we examined $\mathrm{PKC} \varepsilon(-/-)$ mice to determine if their increased level of response to ethanol is owing to increased initial sensitivity or decreased AFT and is related to altered regulation of $\mathrm{GABA}_{\mathrm{A}}$ receptors by ethanol. Our findings provide evidence for ethanol-induced activation of a $\mathrm{PKC} \varepsilon$-dependent signaling pathway that contributes to acute tolerance of $\mathrm{GABA}_{\mathrm{A}}$ receptors to ethanol and to AFT but not to chronic tolerance.

\section{MATERIALS AND METHODS}

\section{Animal Care}

A null mutation was generated in the mouse Prkce gene by homologous recombination in embryonic stem cells, as described (Khasar et al, 1999). Male and female PKC\& $(+/-)$ mice maintained on inbred 129S4 and backcrossed ( $>10$ generations) C57BL6/J backgrounds were mated to produce $\mathrm{PKC} \varepsilon(+/-) \mathrm{C} 57 \mathrm{BL} 6 / \mathrm{J} \times 129 \mathrm{~S} 4 \mathrm{~F} 1$ hybrid mice for breeding. These mice were intercrossed to generate F2 hybrid $\mathrm{PKC} \varepsilon(+/+)$ and $\mathrm{PKC} \varepsilon(-/-)$ littermates for experiments. Mice were genotyped by PCR of tail biopsies (5-10 $\mathrm{mm}$ fragment) obtained from nonanesthetized, 10-day-old pups. All animals were male and between 2 and 6 months old at the time of experimentation. We observed no age-related differences in any of the behavioral tests performed. All procedures were conducted in accordance with institutional IACUC policies and the Society for Neuroscience's Policy on the Use of Animals in Neuroscience Research. For each behavioral test, a different group of mice was used.

\section{LORR}

Initial sensitivity to ethanol-induced loss of righting was measured using the 'up and down' method (Dixon, 1965; Findlay et al, 2002) to calculate an $\mathrm{ED}_{50}$ for ethanol-induced LORR. A mouse was given an intraperitoneal (i.p.) injection of $10 \%(\mathrm{v} / \mathrm{v})$ ethanol in saline, and $5 \mathrm{~min}$ later, tested for LORR greater than $1 \mathrm{~min}$. If this first mouse lost the righting reflex, then the next mouse was given a lower ethanol dose. If the first mouse did not lose the righting reflex within
5 min after injection, then the next mouse was given a higher dose. The log dose interval was 0.0138 , corresponding to approximately a $0.1 \mathrm{~g} / \mathrm{kg}$ difference between doses. The $\mathrm{ED}_{50}$ value was determined as described (Findlay et al, 2002), with $95 \%$ confidence intervals (CIs) calculated by the following equation: $95 \% \mathrm{CI}=$ dosing increment $\times$ square root of $(2 / n) \times 1.96$, where $n$ is the the last six trials and 1.96 reflects the $0.05 \propto$ level (Dixon, 1965). When 95\% CIs do not overlap, the $\mathrm{ED}_{50}$ values for each group of animals are considered significantly different.

LORR duration was measured by administering ethanol $(20 \%(\mathrm{v} / \mathrm{v})$ in $0.9 \%$ saline $)$ i.p. in different volumes to obtain two test doses $(3.2$ or $4.0 \mathrm{~g} / \mathrm{kg}$ ). In mice, these concentrations yield LORR durations ranging from 30 to $120 \mathrm{~min}$, and cover the range of doses between the minimum necessary to produce the response and the maximum that will not cause death. After injection, mice were placed on their backs. LORR was defined as the animal being unable to right itself three times within a 30 -s period. The mouse was considered to have recovered the righting reflex when it could right itself three times within a $1 \mathrm{~min}$ time frame. A blood sample was taken from the tail vein at the time of recovery for the determination of blood ethanol concentration (BEC) in mice that had received $4.0 \mathrm{~g} / \mathrm{kg}$ ethanol. Mice were tested at both concentrations of ethanol using a random order, balanced design, with at least 1 week elapsing between test sessions.

\section{Rotarod Ataxia}

On the day preceding testing, ethanol-naïve mice were trained to remain on a rotarod (model 7650; Ugo Basile, Italy) rotating at 14 r.p.m. for a 3-min period. The following day, mice were tested for their ability to stay on the rotarod for $3 \mathrm{~min}$. Mice were then injected with $2.0 \mathrm{~g} / \mathrm{kg}$ ethanol i.p. and placed back on the apparatus at $15,30,45,60,75$, and $90 \mathrm{~min}$ postinjection. The time to fall from the rotarod was recorded for each trial. For each mouse, blood samples were taken $5 \mathrm{~min}$ postinjection and at recovery from ataxia, and were analyzed for BEC.

To measure initial sensitivity to ethanol-induced ataxia, the 'up and down' method was used to calculate the estimated $\mathrm{ED}_{50}$ for ethanol. An i.p. injection of $10 \%$ ethanol $(\mathrm{v} / \mathrm{v})$ in $0.9 \%$ saline was administered and the mouse was immediately placed on the rotarod for $5 \mathrm{~min}$. If the mouse fell off the rotarod twice during the test, it was judged to be ataxic. If the first mouse showed ataxia, then the next mouse was given a lower ethanol dose. If the first mouse did not show ataxia within 5 min after injection, then the next mouse was given a higher dose. The log dose interval was 0.0276 , corresponding to approximately a $0.2 \mathrm{~g} / \mathrm{kg}$ difference between doses. $\mathrm{ED}_{50}$ values and CIs were calculated as described above for ethanol-induced LORR.

\section{Stationary Dowel Test}

For this test, we used a modification of the procedure described by $\mathrm{Wu}$ et al (2001). A horizontal wooden dowel ( $1.27 \mathrm{~cm}$ diameter, $30 \mathrm{~cm}$ long) was suspended between two Plexiglas walls $50 \mathrm{~cm}$ above a cushioned surface. Mice were trained to balance on the dowel for three 1-min periods at 5 -min increments. The mice were considered trained when 
they were able to remain on the rod for more than $1 \mathrm{~min}$. For AFT experiments, each mouse was then given an i.p. injection of $1.5 \mathrm{~g} / \mathrm{kg}$ ethanol $(20 \%(\mathrm{w} / \mathrm{v})$ in saline) and placed on the dowel. After the mouse fell from the dowel, it was retested every $5 \mathrm{~min}$ until it was able to remain on the dowel for at least $1 \mathrm{~min}$, at which time a blood sample was taken (BEC1) by tail vein puncture. Following sample collection, the mouse was immediately given a booster injection of $1.5 \mathrm{~g} / \mathrm{kg}$ ethanol and placed back on the dowel. The time at which the second period of ataxia began was recorded when the animal again fell off the rod. The mouse was retested every 5 min until it was again able to remain on the rod for at least $1 \mathrm{~min}$, at which point a final blood sample (BEC2) was drawn. Some animals were bled $5 \mathrm{~min}$ after the second injection to measure BEC, but were not tested further. Blood samples were centrifuged at $10000 \mathrm{~g}$ and serum blood alcohol concentrations were determined using an Analox AM-1 analyzer (Analox Instruments, Luneburg, MA). AFT was calculated as the difference between BEC2 and BEC1. The rate at which AFT developed was calculated as (BEC2-BEC1)/duration of ataxia following the booster injection. The threshold for sensitivity to ethanol-induced ataxia was calculated by extrapolating the line determined by the BEC2 and BEC1 values to zero time. The rationale for this calculation is based on the evidence indicating that AFT develops linearly with the time of ethanol exposure up to a maximum (Radlow, 1994; Wu et al, 2001).

\section{Ethanol Preference}

Baseline fluid consumption was monitored by allowing mice access to two bottles containing water for 4 days. After baseline levels of fluid intake were determined, mice were given free access to two drinking bottles, one containing an ethanol solution and the other containing water. Bottles and mice were weighed every 2 days to monitor consumption. The side of the cage in which the ethanol bottle was presented (left $v s$ right) was switched every 2 days. The concentration of ethanol $(3,6$, or $10 \%)$ was increased every 3-5 days. Consumption of $10 \%$ ethanol was assessed for 6 days, after which animals were treated twice daily with i.p. injections of $2.5 \mathrm{~g} / \mathrm{kg}$ ethanol for 6 days to establish chronic tolerance to ethanol. Starting on day 7 , they underwent a second session of two-bottle choice drinking with $10 \%$ ethanol for 6 days.

\section{Ethanol Clearance}

Ethanol clearance was determined in ethanol-naïve mice by injecting them with $3.6 \mathrm{~g} / \mathrm{kg}$ of ethanol i.p. and removing $20 \mu \mathrm{l}$ blood samples from the tail vein at 30,60 , and $120 \mathrm{~min}$ postinjection. The following day, chronic treatment was started with animals injected twice daily with $2.5 \mathrm{~g} / \mathrm{kg}$ ethanol i.p. On day 7, mice were retested for ethanol clearance.

\section{Preparation of Cerebellar Microsacs}

Duplicate pairs of animals of each genotype were injected with 2.0 or $4.0 \mathrm{~g} / \mathrm{kg}$ of ethanol i.p. or the equivalent volume of normal saline and $45 \mathrm{~min}$ later cerebella were dissected on ice. Cerebella from each pair were pooled to constitute one sample and microsacs were prepared from each sample using a modification of the method described by Harris and Allan (1985). Samples were homogenized by hand (seven to 10 strokes) using a Teflon-glass homogenizer containing $7 \mathrm{ml}$ of ice-cold assay buffer $(145 \mathrm{mM} \mathrm{NaCl}, 5 \mathrm{mM} \mathrm{KCl}$, $1 \mathrm{mM} \mathrm{MgCl}_{2}, 10 \mathrm{mM}$ glucose, $1 \mathrm{mM} \mathrm{CaCl} 2,10 \mathrm{mM}$ HEPES ( $\mathrm{pH}$ 7.5), using Tris base) plus a Complete Protease Inhibitor Cocktail Tablet (Roche Applied Science, Indianapolis, IN). The homogenate was centrifuged at $950 \mathrm{~g}$ for 5 min, using a Marathon 3200R rotor (Fisher Scientific, Fairlawn, NJ). The pellet was resuspended in assay buffer containing $0.2 \%$ BSA to yield a suspension of $6 \mathrm{mg} / \mathrm{ml}$ protein. It took approximately $15 \mathrm{~min}$ to generate microsacs after killing the mice; thus, the ${ }^{36} \mathrm{Cl}^{-}$uptake assay (see below) was started $1 \mathrm{~h}$ after in vivo injection of ethanol or saline.

\section{${ }^{36} \mathrm{Cl}^{-}$Uptake}

Microsacs $(200 \mu \mathrm{l})$ were incubated at $37^{\circ} \mathrm{C}$ for $5 \mathrm{~min} .{ }^{36} \mathrm{Cl}^{-}$ uptake was started by adding a solution containing ${ }^{36} \mathrm{Cl}^{-}$ $(0.2 \mu \mathrm{Ci} / \mathrm{ml}$ of assay buffer $), 1 \mu \mathrm{M}$ muscimol, or $1 \mu \mathrm{M}$ muscimol plus $20 \mathrm{mM}$ ethanol. After $5 \mathrm{~s}$, the reaction was stopped by adding $4 \mathrm{ml}$ of ice-cold assay buffer containing $100 \mu \mathrm{M}$ picrotoxin followed by rapid vacuum filtration over $2.5 \mathrm{~cm} \mathrm{GF/C} \mathrm{Whatman} \mathrm{filters} \mathrm{(Whatman,} \mathrm{Kent,} \mathrm{UK).}$ Filters were washed with an additional $12 \mathrm{ml}$ of cold assay buffer and counted in ScintiVerse scintillation fluid (Fisher Scientific, Fairlawn, NJ) using a scintillation counter. Muscimol-stimulated uptake was calculated as the difference in uptake measured in the presence and absence of muscimol. Ethanol-enhanced ${ }^{36} \mathrm{Cl}^{-}$uptake was expressed as a percentage of uptake measured in the presence of muscimol alone.

\section{Western Analysis of PKCe S729 Phosphorylation}

Pairs of mice were injected with ethanol (1.5 or $4 \mathrm{~g} / \mathrm{kg}$ ) or saline i.p. and were killed by decapitation at indicated times. Brains were rapidly removed, and frontal cortex, cerebellum, and striatum were dissected. Brain tissues were homogenized in lysis buffer containing $20 \mathrm{mM}$ Tris, $10 \mathrm{mM}$ EGTA, $2 \mathrm{mM}$ EDTA, $250 \mathrm{mM}$ sucrose, $1 \mathrm{mM}$ PMSF, $1 \times$ Complete Protease Inhibitor Cocktail (Roche Applied Science, Indianapolis, IN), and a 1:100 dilution of serine/ threonine phosphatase inhibitor cocktail 1 (Sigma-Aldrich, St Louis, MO) on ice. The homogenates were centrifuged at $10000 \mathrm{~g}$ for $10 \mathrm{~min}$ at $4{ }^{\circ} \mathrm{C}$ and the supernatants were collected. Concentrated Laemmli sample buffer was added to yield a final solution containing $62.5 \mathrm{mM}$ Tris- $\mathrm{HCl}$ ( $\mathrm{pH}$ 6.8), 2\% SDS, 5\% $\beta$-mercaptoethanol, $10 \%$ glycerol, and $0.002 \%$ bromophenol blue. Samples were boiled at $90^{\circ} \mathrm{C}$ for $7 \mathrm{~min}$ and then passed through a 28-G needle. Equal amounts of protein $(20 \mu \mathrm{g} / \mathrm{lane})$ were loaded onto $6 \%$ Trisglycine SDS-polyacrylamide gels. In pilot experiments, we determined that $20 \mu \mathrm{g}$ of protein was optimal for detecting at least a two-fold increase in signal while remaining within the linear range of detection for each brain region that we tested. The separated proteins were then electrophoretically transferred to a nitrocellulose membrane (Hybond ${ }^{\mathrm{TM}}-\mathrm{C}$ Extra, Amersham Biosciences, Buckinghamshire, UK). Membranes 
were blocked by incubation with $5 \%$ nonfat dry milk in $0.01 \mathrm{M}$ PBS containing $0.1 \%$ Tween 20 for $1 \mathrm{~h}$ at $25^{\circ} \mathrm{C}$. The membranes were then incubated with anti-phospho-PKC $\varepsilon$ (Ser729) antibody (1:8000 dilution; Santa Cruz Biotechnology, Santa Cruz, CA) or anti-PKCe (Choi et al, 2002; 1:80 000 dilution), and anti-actin antibody (1:20 000 dilution; Sigma) in blocking solution overnight at $4{ }^{\circ} \mathrm{C}$. After being washed with $0.01 \mathrm{M}$ PBS containing $0.1 \%$ Tween 20 (PBS-T) three times for $5 \mathrm{~min}$, the membranes were incubated with goat anti-rabbit IgG-peroxidase-conjugated antibody (1:1000 dilution; Chemicon, Temecula, CA) in blocking solution for $1.5 \mathrm{~h}$ at $25^{\circ} \mathrm{C}$. Antibody concentrations were based on the manufacturer's recommendations or were determined by pilot experiments conducted to identify concentrations that produced the highest specific immunostaining with the least nonspecific signal. We also confirmed the specificity of our anti-PKC $\varepsilon$ antibody and the commercial anti-phospho-PKC $\varepsilon$ antibody by Western blotting tissue from PKC $\varepsilon(-/-)$ mice and no protein bands were observed (not shown).

After incubation in secondary antibody, the membranes were washed three times for $5 \mathrm{~min}$ in PBS-T. Immunoreactive bands were visualized by chemiluminescence (Pierce, Rockford, IL) and recorded using X-ray film. The optical densities of the immunoreactive bands were quantified using a flat bed scanner and the program Image J (http://rsb.info.nih.gov/ij). Values for phospho-PKC $\varepsilon$ and PKC $\varepsilon$ immunoreactivity were normalized to actin immunoreactivity and the normalized values for each ethanol- and saline-treated pair were divided to yield an ethanol/saline ratio for phospho-PKC $\varepsilon$ and total $\mathrm{PKC} \varepsilon$. The experiment was repeated at least four times for each time point and each dose of ethanol.

\section{RESULTS}

\section{Reduced AFT to Ethanol in PKCe (-I-) Mice}

PKC $\varepsilon(-/-)$ mice show an increased duration of ethanolinduced LORR (Hodge et al, 1999). To determine if this is related to increased initial sensitivity or altered AFT to ethanol, we compared LORR duration and the BEC upon recovery of the righting reflex with the $\mathrm{ED}_{50}$ for ethanol- induced loss of righting. As expected, $\mathrm{PKC} \varepsilon(-/-)$ mice showed a three-fold greater LORR duration when compared with PKC $\varepsilon(+/+)$ littermates (Figure 1a) and the BEC at recovery from $4.0 \mathrm{~g} / \mathrm{kg}$ was $16 \%$ lower in $\mathrm{PKC} \varepsilon(-/-)$ mice compared to $\mathrm{PKC} \varepsilon(+/+)$ mice (Figure $1 \mathrm{~b})$. In addition, the $\mathrm{ED}_{50}$ for inducing loss of righting was decreased by about $8 \%$ in $\mathrm{PKC} \varepsilon(-/-)$ mice when compared with $\mathrm{PKC} \varepsilon(+/+)$ mice (Figure 1c). This indicates that $\mathrm{PKC} \varepsilon$ modulates initial sensitivity, and possibly AFT, to the hypnotic effect of $4 \mathrm{~g} / \mathrm{kg}$ ethanol.

To investigate how $\mathrm{PKC} \varepsilon$ modulates the level of response to lower ethanol concentrations, we measured rotarod ataxia induced by $2.0 \mathrm{~g} / \mathrm{kg}$ ethanol. At $5 \mathrm{~min}$ after the injection, the latencies to fall were similar $(p=0.29)$ in $\mathrm{PKC} \varepsilon(+/+)$ mice $(7 \pm 2 \mathrm{~s})$ and $\mathrm{PKC} \varepsilon(-/-)$ mice $(4 \pm 1 \mathrm{~s})$ (Figure 2a). The BECs were also similar $(p=0.18)$ in wild-type $(247 \pm 8 \mathrm{mg} / \mathrm{dl} ; n=14)$ and $\mathrm{PKC} \varepsilon(-/-)$ mice $(231 \pm 8 \mathrm{mg} / \mathrm{dl} ; n=13)$ at that time. At $15,30,45,60$, and $75 \mathrm{~min}$ postinjection, $\mathrm{PKC} \varepsilon(-/-)$ mice were less able to remain on the rotarod when compared with $\mathrm{PKC} \varepsilon(+/+)$ mice (Figure 2a). The BEC measured upon recovery, when mice were again able to remain on the rod for $3 \mathrm{~min}$, was also significantly lower in $\mathrm{PKC} \varepsilon(-/-)$ mice compared with $\mathrm{PKC} \varepsilon(+/+)$ mice (Figure $2 \mathrm{~b})$. These findings suggested that the initial sensitivity to ethanol was similar, but that recovery, and therefore development of AFT, was more rapid in the wild-type animals. However, because the initial fall latencies measured $5 \mathrm{~min}$ after ethanol injection were very short (less than $10 \mathrm{~s}$ ), we may have missed detecting a difference in initial sensitivity to $2.0 \mathrm{~g} / \mathrm{kg}$ ethanol by this assay. Therefore, we also measured the $\mathrm{ED}_{50}$ for inducing rotarod ataxia, and found it to be similar in $\mathrm{PKC} \varepsilon(+/+)$ and $\mathrm{PKC} \varepsilon(-/-)$ mice (Figure 2c). Taken together, these data suggest that $\mathrm{PKC} \varepsilon$ plays a greater role in AFT than in initial sensitivity to the ataxic effect of $2.0 \mathrm{~g} / \mathrm{kg}$ ethanol.

The assays of LORR and rotarod ataxia provide only indirect information about AFT. AFT to ethanol-induced impairment of balance can be directly measured using a stationary dowel test (Erwin et al, 2000; Wu et al, 2001). To perform this test, we followed the method used by Erwin et al (2000), which compares the response to two sequential doses of ethanol; however, we used lower ethanol doses
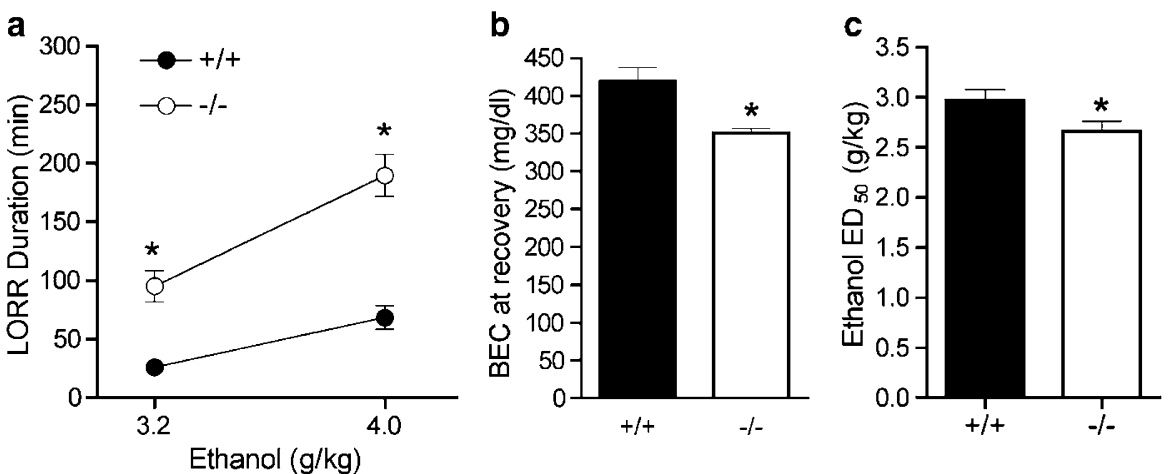

Figure I Ethanol-induced LORR. (a) LORR duration was increased in PKC $\varepsilon(-/-)$ mice. Data are mean \pm SE values from seven to I 3 mice per genotype Two-way ANOVA showed main effects of genotype $(F(I, 32)=67.64 ; p<0.00 I)$ and dose $(F(I, 32)=35.13 ; p<0.00 I)$ with an interaction between these factors $(F(I, 32)=5.036 ; p=0.0319)$. $* p<0.001$ compared with $\mathrm{PKC} \varepsilon(+/+)$ mice by post hoc Bonferroni tests. (b) The BEC upon regaining the righting reflex was higher in wild-type mice $(n=7)$ when compared with PKC $\varepsilon(-/-)(n=8)$ mice $(p<0.003$, two-tailed $t$-test). (c) The ethanol ED 50 to induce loss of righting was lower in $\mathrm{PKC}_{\varepsilon}(-/-)$ mice. Data are mean values $\pm 95 \%$ Cls from six mice per genotype. 
$(1.5 \mathrm{~g} / \mathrm{kg})$ as two sequential higher doses of $2.0 \mathrm{~g} / \mathrm{kg}$ produced loss of righting in some animals after the second dose. This method generates three measures: the magnitude of AFT, the rate at which AFT develops, and the level of initial sensitivity (see Materials and methods). We found that the magnitude of AFT and the rate at which AFT
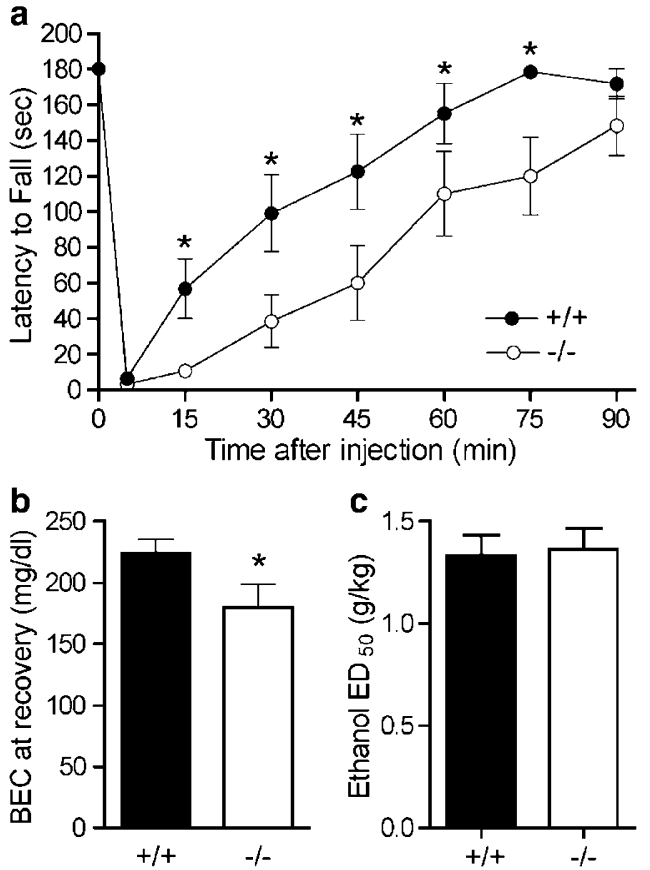

Figure 2 (a) $\operatorname{PKC}_{\varepsilon}(-1-)$ mice $(n=12)$ were less able to remain on the rotarod than $\mathrm{PKC}_{\varepsilon}(+/+)$ mice $(n=13)$ for $15-75 \mathrm{~min}$ after receiving $2.0 \mathrm{~g} / \mathrm{kg}$ ethanol. Two-way, repeated measures ANOVA showed main effects of genotype $(F(I, I 54)=7.90 ; p=0.0 I)$ and time $(F(7, I 54)=52.80$; $p<0.00 \mathrm{I})$, with an interaction between these factors $(F(7, I 54)=2.128$; $p=0.044) .{ }^{*} p<0.05$ compared with $\mathrm{PKC} \varepsilon(+/+)$ mice at the same time by post hoc Newman-Keuls tests. (b) The BEC at recovery from rotarod ataxia was lower for $\mathrm{PKC} \varepsilon(-/-)$ mice $(n=7)$ compared with $\mathrm{PKC} \varepsilon(+/+)$ mice $(n=9)$. ${ }^{*} p<0.05$ by two-tailed t-tests. (c) The $\mathrm{ED}_{50}$ for ethanolinduced ataxia was similar for PKC $\varepsilon(-/-)$ and $\mathrm{PKC}_{\varepsilon}(+/+)$ mice. Data are mean values $\pm 95 \% \mathrm{Cls}$ from six mice per genotype. developed were lower in $\mathrm{PKC} \varepsilon(-/-)$ mice when compared with $\mathrm{PKC} \varepsilon(+/+)$ littermates (Figure $3 \mathrm{a}$ and $\mathrm{b}$ ). In contrast, the initial sensitivity to ethanol was similar between the genotypes (Figure 3c).

\section{Chronic Tolerance to Ethanol}

As $\mathrm{PKC} \varepsilon(-/-)$ mice showed decreased AFT, we investigated whether they also show reduced chronic tolerance to ethanol. Chronic tolerance is associated with accelerated development and increased magnitude of within-session tolerance in the stationary dowel test ( $\mathrm{Wu}$ et al, 2001). Therefore, to measure chronic tolerance by this method, we treated both $\mathrm{PKC} \varepsilon(+/+)$ and $\mathrm{PKC} \varepsilon(-/-)$ mice with twice daily injections of $2.5 \mathrm{~g} / \mathrm{kg}$ ethanol for 6 days and retested them on the stationary dowel. Following chronic ethanol exposure, the magnitude of within-session tolerance and the rate at which it developed increased significantly in both PKC $\varepsilon(+/+)$ and PKC $\varepsilon(-/-)$ mice to the extent that there was no longer a difference between the genotypes in these measures (Figure $3 \mathrm{a}$ and $\mathrm{b}$ ). The change in within-session tolerance was greater in PKC $\varepsilon(-I-)$ mice, which showed a 3.9-fold increase in AFT and a 6.8-fold increase in AFT rate, as compared with $\mathrm{PKC} \varepsilon(+/+)$ mice, which showed only a 1.4-fold increase in AFT and a 2.4-fold increase in AFT rate. Chronic ethanol exposure had no effect on initial sensitivity in either genotype (Figure 3c).

To determine if chronic tolerance to higher doses of ethanol also develops in PKC $\varepsilon(-I-)$ mice, we measured the ethanol-induced LORR in mice treated with twice-daily injections of $2.5 \mathrm{~g} / \mathrm{kg}$ ethanol for 6 days. Following chronic ethanol exposure, PKC $\varepsilon(+/+)$ and $\mathrm{PKC} \varepsilon(-/-)$ mice both showed a decrease in LORR duration in response to acute administration of $3.6 \mathrm{~g} / \mathrm{kg}$ ethanol, and there was no longer a difference in LORR duration between the genotypes (Figure 4a). The percent decrease in LORR duration that occurred with tolerance development was greater in PKC $\varepsilon$ $(-/-)$ than in PKC $\varepsilon(+/+)$ mice (Figure $4 \mathrm{~b})$. These results indicate that absence of $\mathrm{PKC} \varepsilon$ does not impair the development of chronic tolerance to ethanol and may instead enhance it.
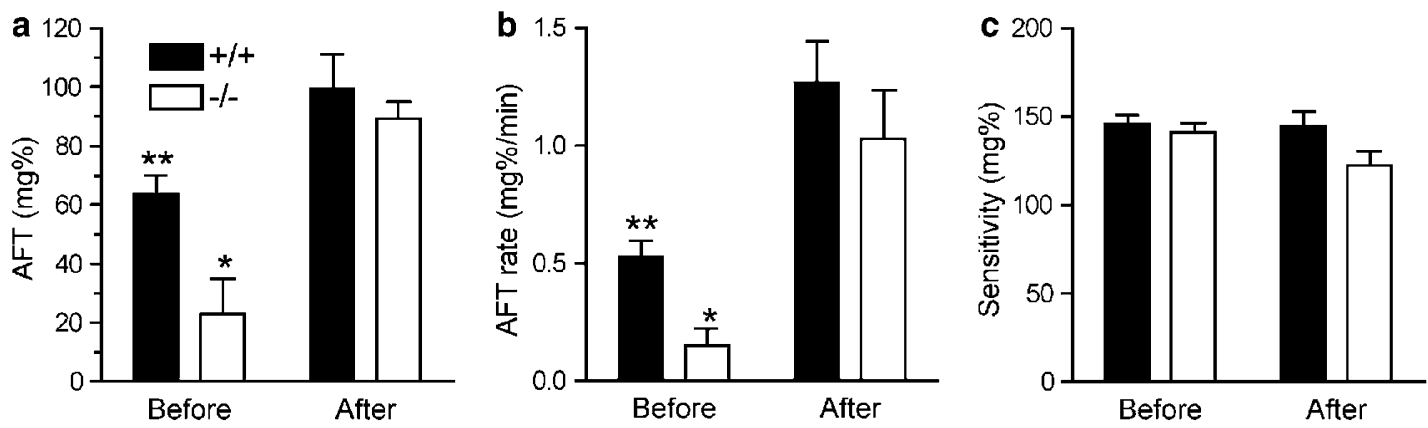

Figure 3 Ethanol-induced loss of balance on the stationary dowel before and after chronic ethanol exposure. AFT magnitude (a) and rate (b) were initially greater in wild-type mice compared with $\mathrm{PKC} \varepsilon(-/-)$ mice ('Before'), but chronic ethanol exposure increased AFT magnitude and AFT rate in both genotypes so that there was no longer a difference between the genotypes ('After'). Two-way ANOVA for AFT magnitude showed main effects of genotype $(F(I, 57)=7.56 ; p=0.008)$ and treatment $(F(I, 57)=30.08 ; p<0.000 I)$. For AFT rate, there were also main effects of genotype $(F(I, 5 I)=4.92$; $p<0.03 \mathrm{I})$ and treatment $(\mathrm{F}(\mathrm{I}, 5 \mathrm{I})=34.04 ; p<0.000 \mathrm{I})$. ${ }^{*} p<0.05$ compared with $\mathrm{PKC} \varepsilon(+/+)$ mice before and with $\mathrm{PKC} \varepsilon(-/-)$ mice after chronic ethanol exposure; ** $<0.05$ compared with $\mathrm{PKC}_{\varepsilon}(+/+)$ mice after chronic ethanol exposure (Bonferroni tests). (c) There was no change in calculated initial sensitivity to ethanol-induced ataxia in either genotype before or after chronic ethanol exposure. Data are mean \pm SEM values from II to I 8 mice per genotype for each treatment condition. 


\section{Acute Tolerance to Ethanol Enhancement of $\mathrm{GABA}_{\mathrm{A}}$ Receptor Function}

PKC $\varepsilon$ is abundant in the cerebellum (Choi et al, 2002) and ethanol's actions on cerebellar neurons appear to contribute to hypnotic and ataxic effects of ethanol (Palmer et al, 1987; Clark and Dar, 1988). A single exposure to ethanol in vivo reduces ethanol enhancement of $\mathrm{GABA}_{\mathrm{A}}$ receptor function measured in vitro in cerebellar microsacs $1 \mathrm{~h}$ later; this effect has been proposed as a mechanism underlying AFT to ethanol (Allan and Harris, 1987). As $\mathrm{GABA}_{\mathrm{A}}$ receptor modulation by ethanol is increased in $\mathrm{PKC} \varepsilon(-/-)$ mice (Hodge et al, 1999; Choi et al, 2002), we examined whether cerebellar $\mathrm{GABA}_{\mathrm{A}}$ receptors from PKC $\varepsilon(-I-)$ mice show acute tolerance to ethanol. We treated mice with 2.0 or
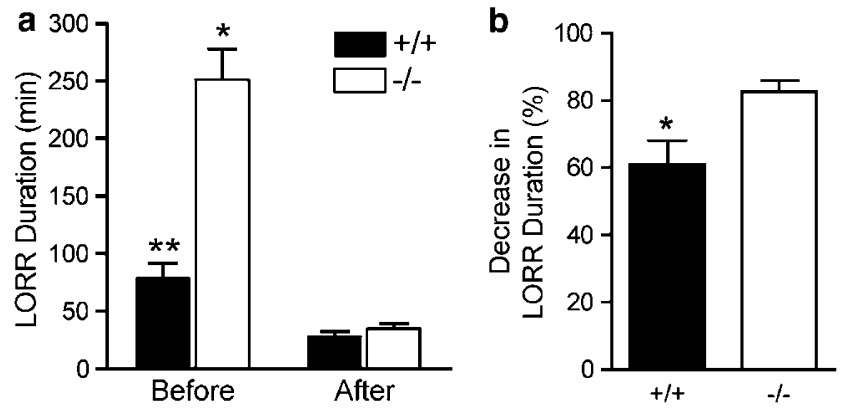

Figure 4 Duration of the ethanol-induced LORR before and after chronic ethanol treatment. (a) The duration of the LORR was greater in PKC $\varepsilon(-/-)$ mice compared with $\mathrm{PKC} \varepsilon(+/+)$ mice before chronic ethanol exposure, but after chronic exposure, it was reduced in both genotypes and there was no longer a difference between them. Two-way ANOVA showed main effects of genotype $(F(I, 27)=28.02 ; p<0.00 I)$ and treatment $(F(I, 27)=62.04 ; p<0.00 I)$ with an interaction between these factors $(F(I, 27)=23.73 ; p<0.00 I)$. $* 0<0.05$ compared with $\mathrm{PKC}_{\varepsilon}(+/+)$ mice before and with $\mathrm{PKC} \varepsilon(-/-)$ mice after chronic ethanol exposure and ** $p<0.05$ compared with $\mathrm{PKC}_{\varepsilon}(+/+)$ mice after chronic ethanol exposure (post hoc Tukey's tests). (b) The percent decrease in LORR duration that accompanied chronic treatment with alcohol was greater in PKC $\varepsilon(-/-)$ than in PKC $\varepsilon(+/+)$ mice $(* p<0.05$ by two-tailed $t$-test).
$4.0 \mathrm{~g} / \mathrm{kg}$ ethanol i.p. or an equivalent volume of saline and $45 \mathrm{~min}$ later isolated cerebellar microsacs to examine muscimol-stimulated ${ }^{36} \mathrm{Cl}^{-}$uptake. As shown previously (Hodge et al, 1999), uptake stimulated by the direct $\mathrm{GABA}_{\mathrm{A}}$ receptor agonist muscimol was similar in microsacs from PKC $\varepsilon(-I-)$ and $\mathrm{PKC} \varepsilon(+/+)$ mice treated with saline or ethanol in vivo (Figure 5a). Also as shown previously (Hodge et al, 1999), muscimol-stimulated uptake was increased by the addition of $20 \mathrm{mM}$ ethanol in vitro to a greater extent in microsacs from saline-injected PKC $\varepsilon$ $(-/-)$ mice when compared with microsacs from salineinjected $\mathrm{PKC} \varepsilon(+/+)$ mice (Figure $5 \mathrm{~b}$ and $\mathrm{c}$ ). In vivo treatment with 2.0 (Figure $5 \mathrm{~b}$ ) or $4.0 \mathrm{~g} / \mathrm{kg}$ (Figure $5 \mathrm{c}$ ) ethanol reduced the ability of in vitro $20 \mathrm{mM}$ ethanol to enhance muscimol-stimulated uptake in $\mathrm{PKC} \varepsilon(+/+)$ microsacs but had no effect on uptake in microsacs from $\mathrm{PKC} \varepsilon(-/-)$ mice. These results indicate that $\mathrm{PKC} \varepsilon$ is required for acute tolerance of cerebellar $\mathrm{GABA}_{\mathrm{A}}$ receptors to ethanol.

\section{Ethanol Treatment Increases PKCE S729 Phosphorylation in the Cerebellum}

We next considered whether ethanol regulates $\mathrm{PKC} \varepsilon$. As there are no specific substrates of $\mathrm{PKC} \varepsilon$ that have been identified, it is not yet possible to assay $\mathrm{PKC} \varepsilon$ activity in intact cells or tissues. $\mathrm{PKC} \varepsilon$, like other $\mathrm{PKC}$ isozymes, undergoes a series of post-translational phosphorylation events that result in a mature, phosphorylated enzyme capable of being fully activated by lipid second messengers (Newton, 2003) and these events can be assayed using phosphorylation-site-specific anti-PKC $\varepsilon$ antibodies (Parekh et al, 1999; Takahashi et al, 2000; Cenni et al, 2002). Unlike conventional $\mathrm{PKC} \alpha,-\beta$, or $-\gamma$ isozymes, which are constitutively phosphorylated, there is a pool of unphosphorylated and inactive PKC $\varepsilon$ that is stable within cells and can be recruited into cell signaling pathways by activation of phosphoinositide 3-kinase, which leads to the phosphorylation of the activation loop of PKC $\varepsilon$ at T566 by phospholipid-
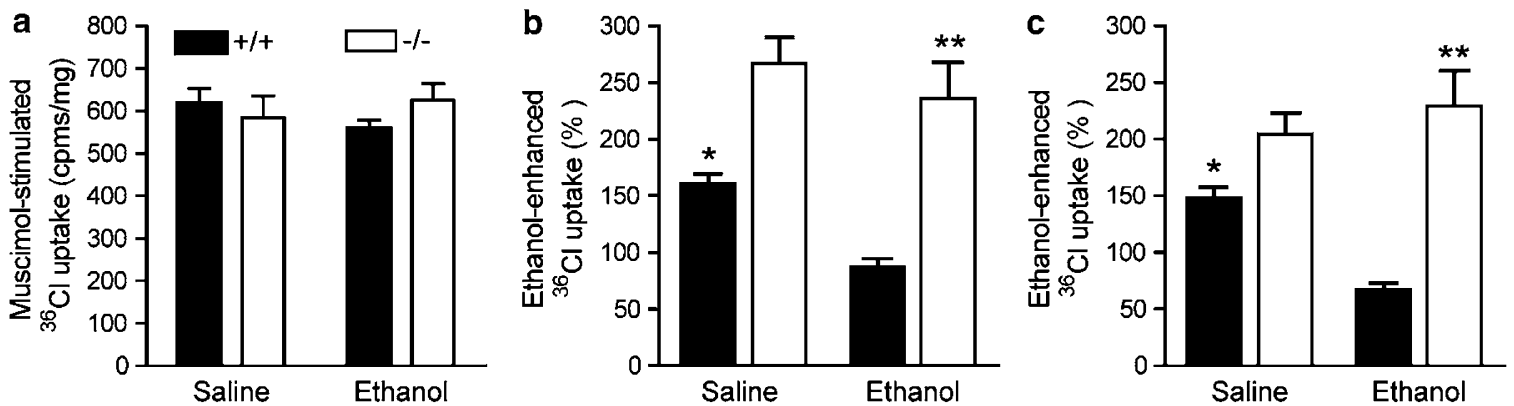

Figure 5 Acute tolerance of cerebellar GABA receptors to ethanol. (a) ${ }^{36} \mathrm{Cl}^{-}$uptake stimulated by muscimol alone was not different between microsacs from $\mathrm{PKC} \varepsilon(-/-)$ mice (open bars) and $\mathrm{PKC} \varepsilon(+/+)$ mice (filled bars) and was not affected by prior in vivo exposure to $4 \mathrm{~g} / \mathrm{kg}$ ethanol in either genotype. (b and c) Addition of $20 \mathrm{mM}$ ethanol in vitro enhanced muscimol-stimulated ${ }^{36} \mathrm{Cl}^{-}$uptake to a greater extent in microsacs prepared from saline-injected PKC $\varepsilon(-/-)$ mice (open bars) as compared to microsacs from saline-injected PKC $\varepsilon(+/+$ ) mice (filled bars). Exposure to $2 \mathrm{~g} / \mathrm{kg}$ (b) or $4 \mathrm{~g} / \mathrm{kg}$ (c) ethanol in vivo, blocked enhancement of muscimol-stimulated ${ }^{36} \mathrm{Cl}^{-}$flux by $20 \mathrm{mM}$ ethanol in vitro in microsacs from PKC $\varepsilon(+/+)$ mice but not in microsacs from PKC $\varepsilon(-1-)$ mice. Two-way ANOVA for mice treated with $2.0 \mathrm{~g} / \mathrm{kg}$ ethanol showed main effects of genotype $(F(I, 33)=26.87 ; p<0.000 \mathrm{I})$ and in vivo treatment $(F(I, 33)=4.48 ; p=0.042)$. $* p<0.05$ compared to microsacs from saline-treated PKC $\varepsilon(-l-)$ mice and microsacs from ethanol-treated PKC $\varepsilon(+/+)$ mice; $* *$ $p<0.05$ compared with microsacs from ethanol-treated PKC $\varepsilon(+/+)$ mice (post hoc Newman-Keuls tests). Two-way ANOVA for mice treated with $4.0 \mathrm{~g} / \mathrm{kg}$ ethanol showed a main effect of genotype $(F(I, I 3)=51.78 ; p<0.000 \mathrm{I})$ and an interaction between in vivo treatment and genotype $(\mathrm{F}(\mathrm{I}, \mathrm{I} 3)=12.10 ; p=0.004 \mathrm{I})$. $* 0<0.05$ compared to microsacs from saline-treated PKC $\varepsilon(-/-)$ mice and microsacs from ethanol-treated PKC $\varepsilon(+/+)$ mice; $* *$ $p<0.05$ compared with microsacs from ethanol-treated PKC $\varepsilon(+/+)$ mice (post hoc Bonferroni tests). 
dependent kinase 1 (Cenni et al, 2002). Phosphorylation at this site is required for enzymatic activity (Parekh et al, 1999; Takahashi et al, 2000). This permits autophosphorylation at T710 and subsequent phosphorylation at S729 either by autophosphorylation (Cenni et al, 2002) or by a different kinase (Parekh et al, 1999). Phosphorylation at $\$ 729$ permits full activity of $\mathrm{PKC} \varepsilon$ when the enzyme is stimulated by lipid second messengers (Parekh et al, 1999; Takahashi et al, 2000). Thus, PKC $\varepsilon$ phosphorylation at $\mathrm{S} 729$ has been used as a marker for activation and posttranslational processing of the immature pool of PKC $\varepsilon$ that is not yet fully phosphorylated (Saitoh et al, 2001; Bayer et al, 2003; Zhou et al, 2003; Olive et al, 2005). Therefore, we used a phospho-specific antibody that detects phosphorylation of PKC $\varepsilon$ at $\mathrm{S} 729$ to investigate the regulation of the immature $\mathrm{PKC} \varepsilon$ pool by ethanol.

Treatment with 1.5 or $4 \mathrm{~g} / \mathrm{kg}$ ethanol i.p. increased phospho-S729-PKC $\varepsilon$ immunoreactivity in the cerebellum of PKC $\varepsilon(+/+)$ mice when compared to saline-treated mice (Figure $6 \mathrm{a}$ and $\mathrm{b}$ ). Compared to the cerebellum, phosphoS729-PKC $\varepsilon$ immunoreactivity in the frontal cortex and the striatum was relatively high in saline-treated mice and was not increased further by in vivo ethanol administration (Figure 6a). The ethanol-induced increase in cerebellar phospho-S729-PKC $\varepsilon$ was detected $60 \mathrm{~min}$, but not $30 \mathrm{~min}$ after in vivo ethanol administration (Figure 6b). Ethanol

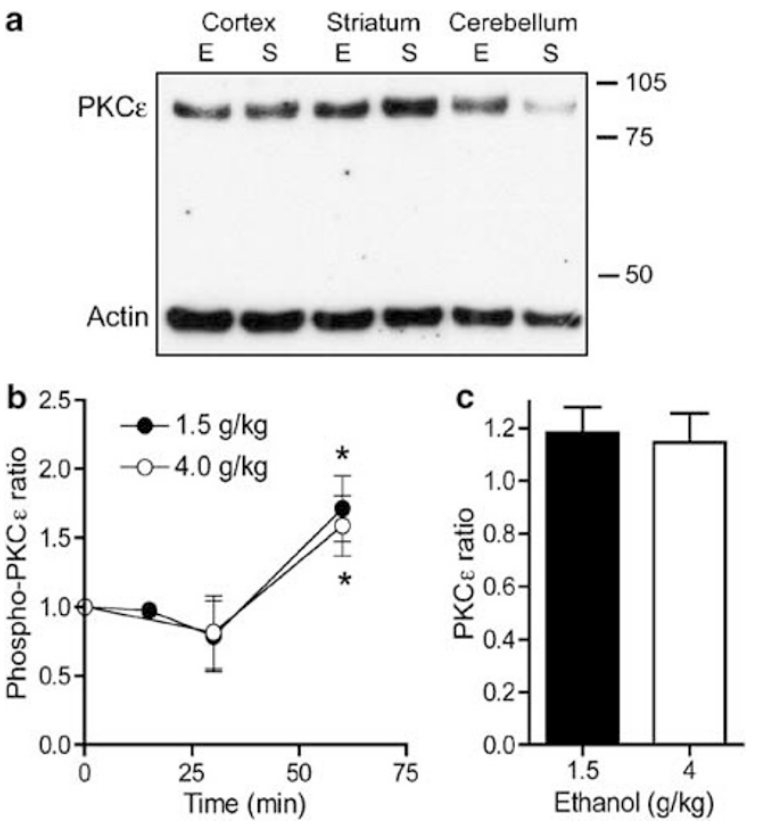

Figure 6 Phospho-PKC $\varepsilon$ immunoreactivity following in vivo ethanol treatment. (a) Pairs of mice were injected with $4 \mathrm{~g} / \mathrm{kg}$ ethanol (E) or saline (S) and killed I h later. Shown is a representative Western blot demonstrating an ethanol-induced increase in phospho-PKC $\varepsilon$ immunoreactivity ( $92 \mathrm{kDa}$ bands) relative to actin ( $43 \mathrm{kDa}$ bands) in the cerebellum, but not in the striatum or the frontal cortex. (b) Time course of ethanolinduced increases in phospho-PKC $\varepsilon$ immunoreactivity in mice injected with 1.5 or $4 \mathrm{~g} / \mathrm{kg}$ ethanol. One-way ANOVA showed an effect of time in mice treated with $1.5 \mathrm{~g} / \mathrm{kg}(F(3,22)=5.91 ; p=0.005)$ or $4 \mathrm{~g} / \mathrm{kg}(F(2,22)=5.148$; $p=0.0147)$ ethanol. $* p<0.05$ compared with zero time (Dunnett's tests). (c) Injection with 1.5 or $4 \mathrm{~g} / \mathrm{kg}$ ethanol in vivo did not alter the abundance of total cerebellar $\mathrm{PKC} \varepsilon$ immunoreactivity relative to actin immunoreactivity measured I h later. treatment did not alter the amount of total cerebellar PKC $\varepsilon$ immunoreactivity (Figure 6c).

\section{Ethanol Preference Following Chronic Tolerance}

We previously found that $\mathrm{PKC} \varepsilon(-/-)$ mice self-administer less ethanol than PKC $\varepsilon(+/+)$ mice in both a two-bottle choice procedure (Hodge et al, 1999) and in an operant paradigm (Olive et al, 2000). We hypothesized that if chronic tolerance to the hypnotic and ataxic effects of ethanol is an important determinant of ethanol preference, then ethanol preference drinking might increase in PKC $\varepsilon$ $(-I-)$ mice following chronic ethanol exposure, when PKC $\varepsilon$ $(-/-)$ mice displayed chronic tolerance to ethanol. To test this, we assessed two-bottle choice drinking of $10 \%$ ethanol and water in PKC $\varepsilon(-/-)$ and $\mathrm{PKC} \varepsilon(+/+)$ mice before and after exposure to twice daily injections of $2.5 \mathrm{~g} / \mathrm{kg}$ ethanol for 6 days. Before chronic ethanol treatment, PKC $\varepsilon(-I-)$ mice consumed less ethanol (Figure 7a) and showed reduced preference for ethanol (Figure $7 \mathrm{~b}$ ) when compared with PKC $\varepsilon(+l+)$ mice. This pattern of drinking remained unchanged following parenteral administration of ethanol for 6 days.

\section{Ethanol Clearance Following Chronic Ethanol Exposure}

Genotype-related changes in ethanol-induced behaviors could be owing to changes in ethanol clearance rather than in tolerance to ethanol. PKC $\varepsilon(-I-)$ and PKC $\varepsilon(+/+)$ mice do not differ in their rate of ethanol clearance when examined in the ethanol-naïve state (Hodge et al, 1999). To determine if this is true following repeated ethanol exposure, we analyzed BECs following injection of $3.6 \mathrm{~g} / \mathrm{kg}$ ethanol before and after chronic exposure to ethanol, $2.5 \mathrm{~g} / \mathrm{kg}$, twice daily, for 6 days (Figure 8 ). We found no difference between genotypes or any effect of chronic ethanol exposure on these measurements.
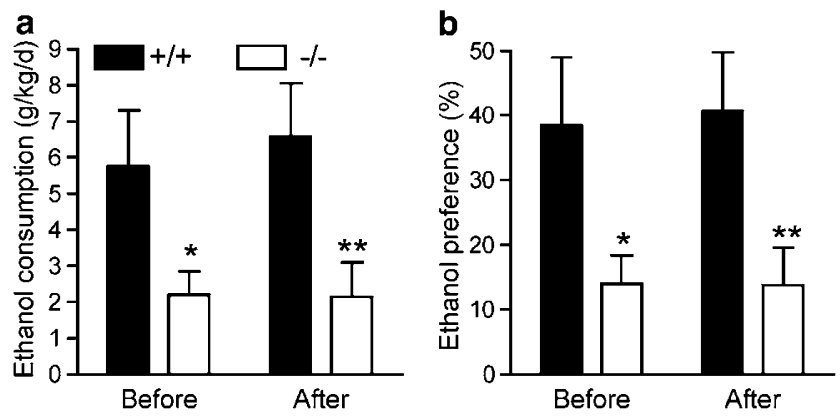

Figure 7 Two-bottle choice ethanol consumption and preference before and after chronic ethanol exposure. PKC $\varepsilon(-/-)$ mice showed decreased consumption of $10 \%(\mathrm{v} / \mathrm{v})$ ethanol (a) and preference for the ethanol containing solution (b) before and after chronic ethanol treatment when compared with $\mathrm{PKC} \varepsilon(+/+)$ mice. For ethanol consumption, twoway ANOVA showed a main effect of genotype $(F(I, 25)=9.41$; $p=0.005 \mathrm{I})$ but not of treatment $(F(I, 25)=0.088 ; p>0.05)$. For ethanol preference, there was also a main effect of genotype $(F(1,25)=9.24$; $p=0.0055)$ but not of treatment $(F(1,25)=0.014 ; p>0.05)$. $* p<0.05$ compared with $\mathrm{PKC}_{\varepsilon}(+/+)$ mice before and $* * * 0.05$ compared with PKC $\varepsilon(+/+)$ mice after chronic treatment with ethanol (Newman-Keuls tests). 


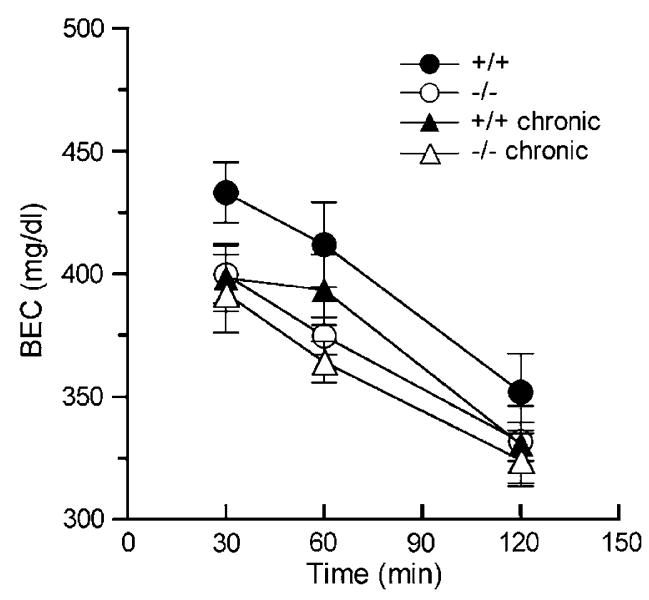

Figure 8 Ethanol clearance before and after chronic treatment. BECs in samples from $\mathrm{PKC}_{\varepsilon}(-/-)(\bigcirc, \triangle)$ and $\mathrm{PKC}_{\varepsilon}(+/+)(\boldsymbol{O}, \boldsymbol{\Delta})$ mice obtained following an acute injection of $3.6 \mathrm{~g} / \mathrm{kg}$ ethanol before $(O, \mathbf{O})$ or after $(\triangle, \mathbf{\Delta})$ chronic ethanol exposure. Analysis of these data by three-way ANOVA with genotype and prior chronic ethanol treatment as betweensubject factors and time as a repeated measure revealed a main effect of time $(F(2,28)=33.6 ; p<0.001)$ without significant effects of genotype $(F(I, \mid 4)=4 . \mid 8 ; p>0.05)$ or prior ethanol treatment $(F(I, I 4)=3.9 \mid$; $p>0.05)$, or an interaction between these variables.

\section{DISCUSSION}

Our findings establish that $\mathrm{PKC} \varepsilon$ contributes to AFT to the ataxic and hypnotic effects of ethanol. We found that the duration of the ethanol-induced LORR and the extent of ethanol-induced rotarod ataxia were increased in mice lacking $\mathrm{PKC} \varepsilon$. Likewise, recovery from each behavioral task occurred at lower BEC's in PKC $\varepsilon(-I-)$ than in PKC $\varepsilon(+/+)$ mice. This was associated with a decrease in the $\mathrm{ED}_{50}$ for the initiation of ethanol-induced loss of righting indicating that $\mathrm{PKC} \varepsilon$ contributes to hypnotic sensitivity to ethanol. In contrast, the $\mathrm{ED}_{50}$ concentration of ethanol that produced rotarod ataxia was not different in wild-type and $\mathrm{PKC} \varepsilon(-/-)$ mice, suggesting that the major effect of PKC $\varepsilon$ is to regulate AFT rather than initial sensitivity to ethanolinduced ataxia. We observed a similar effect of PKC $\varepsilon$ on AFT to ethanol-induced loss of balance on the stationary dowel where we found that both the magnitude and rate at which AFT developed were reduced in PKC $\varepsilon(-I-)$ mice by about $50 \%$ compared with wild-type littermates. In contrast, the calculated initial sensitivity to ethanol-induced loss of balance on the stationary dowel was similar between genotypes. Together, these results suggest that $\mathrm{PKC} \varepsilon$ participates in the development of AFT to the motorimpairing effects of ethanol in mice.

In contrast to its role in AFT, PKC $\varepsilon$ does not appear to mediate chronic tolerance to the hypnotic or ataxic effects of ethanol. PKC $\varepsilon(+/+)$ and PKC $\varepsilon(-I-)$ mice treated with $2.5 \mathrm{~g} / \mathrm{kg}$ ethanol twice daily for 6 days developed chronic tolerance to ethanol-induced LORR and to ethanol-induced ataxia on the stationary dowel such that at the end of the treatment period, there was no longer a difference between the genotypes in these behaviors. We therefore conclude that PKC $\varepsilon$ contributes to AFT in ethanol-naïve mice but does not promote the development of chronic tolerance. Rather, our results suggest that $\mathrm{PKC} \varepsilon$ impairs the develop- ment of chronic tolerance as PKC $\varepsilon(-/-)$ mice showed a greater decrease in LORR than wild-type mice after chronic treatment and therefore developed chronic tolerance to a greater extent than wild-type mice (Figure $4 \mathrm{~b}$ ). Likewise, after chronic ethanol exposure, $\mathrm{PKC} \varepsilon(-I-)$ mice showed a greater increase in AFT and in AFT rate than PKC $\varepsilon(+/+)$ mice on the stationary dowel. These results resemble those described for lines of mice selected for high (HAFT) and low (LAFT) AFT to ethanol (Wu et al, 2001). These mice show genotypic differences in AFT when alcohol naïve but, following chronic ethanol exposure, show equivalent responses to ethanol-induced loss of balance on the stationary dowel and ethanol-induced LORR. Together with our findings, these results indicate that AFT and chronic tolerance can be genetically dissociated.

Tolerance to ethanol has been proposed to promote increased ethanol consumption through two mechanisms: tolerance to the rewarding effects of the drug, requiring that a subject drink more to achieve a pleasurable effect, and tolerance to its aversive properties, which reduces a disincentive to drink (Kalant, 1996). However, we found that despite treatment that produced chronic tolerance to motor impairing and hypnotic effects of ethanol as well as increased AFT, both PKC $\varepsilon(+/+)$ and $\mathrm{PKC} \varepsilon(-/-)$ showed no change in ethanol preference drinking. These results indicate that AFT and chronic tolerance to ataxic and hypnotic effects of ethanol can be dissociated from ethanol preference drinking and suggest that these behaviors, at least in part, involve distinct neural systems.

As the PKC $\varepsilon$ null allele is present from birth, the phenotypes we observed could be owing to changes in the nervous system resulting from the absence of PKC $\varepsilon$ during development. In addition, since the null allele was generated on a 129S4 background and we studied hybrid C57BL/ $6 \times 129$ S4 mice, it is possible that the behavioral phenotypes we observed were due to 129S4 alleles neighboring the PKC $\varepsilon$ locus, and not to the PKC $\varepsilon$ null mutation. However, we previously showed that conditional rescue of $\mathrm{PKC} \varepsilon$ using a tetracycline-regulated transgene restores hypnotic responses to ethanol in PKC $\varepsilon(-/-)$ mice to wild-type levels (Choi et al, 2002). Thus, differences in behavior on the LORR test are unlikely to be owing to developmental effects or neighboring genes. We have not examined AFT to ethanol-induced ataxia using transgenic rescue or inbred 129S4 mice and therefore cannot entirely eliminate the possibility that our results are owing to neighboring genes or developmental changes for these phenotypes.

An additional finding in this study was that in vivo exposure to 2.0 or $4.0 \mathrm{~g} / \mathrm{kg}$ ethanol led to $\mathrm{GABA}_{\mathrm{A}}$ receptor resistance to ethanol measured $60 \mathrm{~min}$ later in cerebellar microsacs from $\mathrm{PKC} \varepsilon(+/+)$ mice. This was similar to findings reported by Allan and Harris (1987), who detected acute tolerance of cerebellar $\mathrm{GABA}_{\mathrm{A}}$ receptors to ethanol in vitro $60 \mathrm{~min}$ after ethanol injection in vivo. Our finding that this response was absent in tissue from $\mathrm{PKC} \varepsilon(-I-)$ mice suggests that it is $\mathrm{PKC} \varepsilon$-dependent. $\mathrm{PKC} \varepsilon$-dependent, acute tolerance of $\mathrm{GABA}_{\mathrm{A}}$ receptors could contribute to the accelerated recovery from ethanol intoxication that we observed in wild-type mice in assays of LORR and ataxia 60 min after ethanol injection. We did not examine $\mathrm{GABA}_{\mathrm{A}}$ receptor function at time points less than $1 \mathrm{~h}$ after ethanol exposure, but Allan and Harris (1987) found no difference 
in ethanol response at $30 \mathrm{~min}$ after ethanol injection. This suggests that other $\mathrm{PKC} \varepsilon$-dependent mechanisms that do not involve cerebellar $\mathrm{GABA}_{\mathrm{A}}$ receptors also contribute to recovery from ethanol-induced rotarod ataxia in wild-type mice, particularly at early time points.

In the stationary dowel test, we injected mice with $1.5 \mathrm{~g} / \mathrm{kg}$ ethanol, which is lower than the doses $(2.0$ and $4.0 \mathrm{~g} / \mathrm{kg})$ that we administered to mice used for $\mathrm{GABA}_{\mathrm{A}}$ receptor studies. However, we used two injections of ethanol in the stationary dowel test and the mean BEC 5 min after the second injection was $311 \pm 11 \mathrm{mg} / \mathrm{dl}(n=11)$. This was significantly greater $(p<0.0001)$ than the mean BEC measured 5 min after injection of a single dose of $2.0 \mathrm{~g} / \mathrm{kg}$ ethanol $(247 \pm$ $8 \mathrm{mg} / \mathrm{dl} ; n=14)$. Therefore, the BECs achieved during the stationary dowel test after the second ethanol injection were within the range of concentrations attained in animals that showed $\mathrm{GABA}_{\mathrm{A}}$ receptor resistance to ethanol in vitro. Moreover, it took an average of $2.32 \pm 0.13 \mathrm{~h}$ for wild-type mice $(n=9)$ to recover on the stationary dowel test after the second ethanol injection, which is much greater than the time $(1 \mathrm{~h})$ needed for development of $\mathrm{GABA}_{\mathrm{A}}$ receptor resistance to ethanol. Therefore, it is likely that acute tolerance of $\mathrm{GABA}_{\mathrm{A}}$ receptors to ethanol contributed to AFT in wild-type mice during the stationary dowel test.

Another finding in this study was that injection of either 1.5 or $4.0 \mathrm{~g} / \mathrm{kg}$ ethanol increased $\mathrm{PKC} \varepsilon$ phosphorylation at S729 in the cerebellum of wild-type mice. As increased phosphorylation of S279 reflects an increase in the amount of PKC $\varepsilon$ that can be fully activated by lipid second messengers (Saitoh et al, 2001; Bayer et al, 2003; Zhou et al, 2003; Olive et al, 2005), these results suggest that ethanol stimulates a signaling cascade that increases the pool size of fully phosphorylated $\mathrm{PKC} \varepsilon$ in the cerebellum. Although ethanol-stimulated $\mathrm{PKC} \varepsilon$ phosphorylation at S729 in wildtype mice, we were only able to measure this increase $60 \mathrm{~min}$ following ethanol injection and not at $30 \mathrm{~min}$ or earlier time points. However, in our study of rotarod ataxia, we observed some recovery in fall latency in wild-type mice as early as $15 \mathrm{~min}$ after injection of $2 \mathrm{~g} / \mathrm{kg}$ ethanol. As we could not detect an increase in PKC 8729 phosphorylation at this time, these results suggest that there are additional PKC\&-dependent mechanisms that contribute to AFT at earlier times $(<60 \mathrm{~min})$, that do not involve post-translational processing of $\mathrm{PKC} \varepsilon$. One possibility is that ethanol activates another signaling pathway that requires the presence of a basal level of PKC $\varepsilon$ activity, or that ethanol increases the production of lipid second messengers, which activate the pre-existing pool of fully phosphorylated, mature $\mathrm{PKC} \varepsilon$ without increasing $\mathrm{PKC} \varepsilon$ processing.

In summary, when taken together with previous studies using $\mathrm{PKC} \varepsilon(-/-)$ mice and peptide inhibitors of $\mathrm{PKC} \varepsilon$, which suggest that $\mathrm{PKC} \varepsilon$ attenuates the $\mathrm{GABA}_{\mathrm{A}}$ receptor response to ethanol (Hodge et al, 1999), our data provide evidence for a negative feedback loop that contributes to acute tolerance of $\mathrm{GABA}_{\mathrm{A}}$ receptors to ethanol. Given the role of cerebellar $\mathrm{GABA}_{\mathrm{A}}$ receptors in hypnotic and ataxic responses to ethanol (Palmer et al, 1987; Clark and Dar, 1988), such a $\mathrm{PKC} \varepsilon-\mathrm{GABA}_{\mathrm{A}}$ receptor signaling pathway could promote AFT to ethanol.

Why $\mathrm{PKC} \varepsilon(-/-)$ mice show reduced ethanol selfadministration remains elusive. It will be important in future work to measure rewarding and aversive properties of ethanol in these animals, especially since ethanol does not elicit dopamine release from the nucleus accumbens of PKC $\varepsilon(-/-)$ mice (Olive et al, 2000), suggesting that these mice might experience less ethanol-induced reward than wild-type animals. We also do not yet know how ethanol stimulates $\mathrm{PKC} \varepsilon$ phosphorylation in the cerebellum or which proteins are phosphorylated by $\mathrm{PKC} \varepsilon$ to regulate the sensitivity of $\mathrm{GABA}_{\mathrm{A}}$ receptors to ethanol. It will be of interest to identify upstream and downstream mediators of these events, as mapping of this signaling pathway could uncover additional proteins besides $\mathrm{PKC} \varepsilon$ that regulate the development of AFT to ethanol, ethanol self-administration, and contribute to risk of alcoholism in humans.

\section{ACKNOWLEDGEMENTS}

This work was supported by National Institutes of Health Grant AA013588 and Department of Defense Grant W81XWH-04-1-0155 to ROM. We thank Patricia Janak for helpful discussions and Christine Orr for technical assistance.

\section{REFERENCES}

Allan AM, Harris RA (1987). Acute and chronic ethanol treatments alter GABA receptor-operated chloride channels. Pharmacol Biochem Behav 27: 665-670.

Bayer AL, Heidkamp MC, Patel N, Porter M, Engman S, Samarel AM (2003). Alterations in protein kinase $C$ isoenzyme expression and autophosphorylation during the progression of pressure overload-induced left ventricular hypertrophy. Mol Cell Biochem 242: 145-152.

Cenni V, Doppler H, Sonnenburg ED, Maraldi N, Newton AC, Toker A (2002). Regulation of novel protein kinase C epsilon by phosphorylation. Biochem J 363: 537-545.

Choi DS, Wang D, Dadgar J, Chang WS, Messing RO (2002). Conditional rescue of protein kinase $\mathrm{C}$ epsilon regulates ethanol preference and hypnotic sensitivity in adult mice. J Neurosci 22: 9905-9911.

Clark M, Dar MS (1988). Mediation of acute ethanol-induced motor disturbances by cerebellar adenosine in rats. Pharmacol Biochem Behav 30: 155-161.

Dick DM, Jones K, Saccone N, Hinrichs A, Wang JC, Goate A et al (2005). Endophenotypes successfully lead to gene identification: results from the Collaborative Study on the Genetics of Alcoholism. Behav Genet (originally published online December 10,2005 , at http://www.springerlink.com/link.asp?id $=$ p4169nm 7148781p7148780).

Dixon WJ (1965). The up-and-down method for small samples. JAMA 60: 967-978.

Erwin VG, Gehle VM, Deitrich RA (2000). Selectively bred lines of mice show response and drug specificity for genetic regulation of acute functional tolerance to ethanol and pentobarbital. J Pharmacol Exp Ther 293: 188-195.

Findlay GS, Wick MJ, Mascia MP, Wallace D, Miller GW, Harris RA et al (2002). Transgenic expression of a mutant glycine receptor decreases alcohol sensitivity of mice. J Pharmacol Exp Ther 300: 526-534.

Harris RA, Allan AM (1985). Functional coupling of gammaaminobutyric acid receptors to chloride channels in brain membranes. Science 228: 1108-1110.

Heath AC, Madden PA, Bucholz KK, Dinwiddie SH, Slutske WS, Bierut LJ et al (1999). Genetic differences in alcohol sensitivity and the inheritance of alcoholism risk. Psychol Med 29: 1069-1081. 
Hodge CW, Mehmert KK, Kelley SP, McMahon T, Haywood A, Olive MF et al (1999). Supersensitivity to allosteric $\mathrm{GABA}_{\mathrm{A}}$ receptor modulators and alcohol in mice lacking PKCe. Nat Neurosci 2: 997-1002.

Hodge CW, Nannini MA, Olive MF, Kelley SP, Mehmert KK (2001). Allopregnanolone and pentobarbital infused into the nucleus accumbens substitute for the discriminative stimulus effects of ethanol. Alcohol Clin Exp Res 25: 1441-1447.

Hu X, Oroszi G, Chun J, Smith TL, Goldman D, Schuckit MA (2005). An expanded evaluation of the relationship of four alleles to the level of response to alcohol and the alcoholism risk. Alcohol Clin Exp Res 29: 8-16.

Kalant H (1996). Current state of knowledge about the mechanisms of alcohol tolerance. Addict Biol 1: 133-141.

Kalant H, LeBlanc AE, Gibbins RJ (1971). Tolerance to, and dependence on, some non-opiate psychotropic drugs. Pharmacol Rev 23: 135-191.

Khasar SG, Lin Y-H, Martin A, Dadgar J, McMahon T, Wang D et al (1999). A novel nociceptor signaling pathway revealed in protein kinase $C \&$ mutant mice. Neuron 24: 253-260.

Newlin DB, Thomson JB (1990). Alcohol challenge with sons of alcoholics: a critical review and analysis. Psychol Bull 108: 383-402.

Newton AC (2003). Regulation of the ABC kinases by phosphorylation: protein kinase $\mathrm{C}$ as a paradigm. Biochem $J 370$ 361-371.

Olive MF, McGeehan AJ, Kinder JR, McMahon T, Hodge CW, Janak PH et al (2005). The mGluR5 antagonist 6-methyl-2(phenylethynyl)pyridine decreases ethanol consumption via a protein kinase C epsilon-dependent mechanism. Mol Pharmacol 67: 349-355.

Olive MF, Mehmert KK, Messing RO, Hodge CW (2000). Reduced operant ethanol self-administration and in vivo mesolimbic dopamine responses to ethanol in PKC $\varepsilon$-deficient mice. Eur $J$ Neurosci 12: 4131-4140.

Palmer MR, Wang Y, Fossom LH, Spuhler KP (1987). Genetic correlation of ethanol-induced ataxia and cerebellar Purkinje neuron depression among inbred strains and selected lines of rats. Alcohol Clin Exp Res 11: 494-501.

Parekh D, Ziegler W, Yonezawa K, Hara K, Parker PJ (1999). Mammalian TOR controls one of two kinase pathways acting upon nPKCdelta and nPKCepsilon. J Biol Chem 274: 34758-34764.
Prescott CA, Kendler KS (1999). Genetic and environmental contributions to alcohol abuse and dependence in a population-based sample of male twins. Am J Psychiatry 156: 34-40.

Proctor WR, Poelchen W, Bowers BJ, Wehner JM, Messing RO, Dunwiddie TV (2003). Ethanol differentially enhances hippocampal $\mathrm{GABA}_{\mathrm{A}}$ receptor-mediated responses in protein kinase $\mathrm{C} \gamma$ (PKC $\gamma)$ and $\mathrm{PKC} \varepsilon$ null mice. J Pharmacol Exp Ther 305: 264-270.

Radlow R (1994). A quantitative theory of acute tolerance to alcohol. Psychopharmacology (Berlin) 114: 1-8.

Saitoh N, Hori T, Takahashi T (2001). Activation of the epsilon isoform of protein kinase $\mathrm{C}$ in the mammalian nerve terminal. Proc Natl Acad Sci USA 98: 14017-14021.

Schuckit MA (1984a). Differences in plasma cortisol after ingestion of ethanol in relatives of alcoholics and controls: Preliminary results. J Clin Psychiatry 45: 374-376.

Schuckit MA (1984b). Subjective responses to alcohol in sons of alcoholics and control subjects. Arch Gen Psychiatry 41: 879-884.

Schuckit MA (1998). Biological, psychological and environmental predictors of the alcoholism risk: a longitudinal study. J Stud Alcohol 59: 485-494.

Schuckit MA, Smith TL (1996). An 8-year follow-up of 450 sons of alcoholic and control subjects. Arch Gen Psychiatry 53: 202-210.

Schuckit MA, Gold E, Risch C (1987). Serum prolactin levels in sons of alcoholics and control subjects. Am J Psychiatry 144: 854-859.

Schuckit MA, Gold EO, Croot K, Finn P, Polich J (1988). P300 latency after ethanol ingestion in sons of alcoholics and in controls. Biol Psychiatry 24: 310-315.

Schuckit MA, Smith TL, Kalmijn J (2004). The search for genes contributing to the low level of response to alcohol: patterns of findings across studies. Alcohol Clin Exp Res 28: 1449-1458.

Takahashi M, Mukai H, Oishi K, Isagawa T, Ono Y (2000). Association of immature hypophosphorylated protein kinase cepsilon with an anchoring protein CG-NAP. J Biol Chem 275: 34592-34596.

Wu PH, Tabakoff B, Szabo G, Hoffman PL (2001). Chronic ethanol exposure results in increased acute functional tolerance in selected lines of HAFT and LAFT mice. Psychopharmacology (Berlin) 155: 405-412.

Zhou Y, Li GD, Zhao ZQ (2003). State-dependent phosphorylation of epsilon-isozyme of protein kinase $\mathrm{C}$ in adult rat dorsal root ganglia after inflammation and nerve injury. J Neurochem 85: 571-580. 